\title{
Quality of pitaya fruit (Hylocereus undatus) as influenced by storage temperature and packaging
}

\author{
Sérgio Tonetto de Freitas ${ }^{1 *}$, Elizabeth Jeanne Mitcham²
}

'Embrapa Semiárido, BR 428, km 152 - 56302-970 Petrolina, PE - Brasil.

2University of California - Dept. of Plant Sciences, One Shields Avenue - 95616 - Davis, CA - USA.

${ }^{*}$ Corresponding author <sergio.freitas@embrapa.br>

Edited by: Daniel Scherer de Moura

Received September 17, 2012

Accepted February 26, 2013
Abstract: Pitaya (Hylocereus undatus) is an exotic non-climacteric fruit that reaches its best eating quality when harvested ripe, decreasing thereafter during storage. Our objectives were to determine the best combination of storage temperature and use of perforated plastic bags to maintain the postharvest quality of the fruit. Fruits were stored at 5,7 , or $10^{\circ} \mathrm{C}$ with and without a perforated plastic bag for 20 days, followed by five days at $20^{\circ} \mathrm{C}$ without the bag for shelf-life determination. Storage at $5{ }^{\circ} \mathrm{C}$, followed by $7{ }^{\circ} \mathrm{C}$ maintained better visual appearance of the pitaya fruit after 20 days, by reducing decay incidence and severity, and maintaining greener bracts compared with fruit stored at $10^{\circ} \mathrm{C}$. Pitaya fruit stored at $5{ }^{\circ} \mathrm{C}$ without a perforated plastic bag showed no decay after storage and shelf-life. In general, higher temperatures and the use of a perforated plastic bag increased decay incidence, as well as decay severity after storage and shelf-life conditions. At all temperatures, fruit stored in a perforated plastic bag had lower weight loss during storage. After shelf-life, weight loss was highest in fruit stored at higher temperatures. Storage of fruits at $5{ }^{\circ} \mathrm{C}$ resulted in minor chilling injury symptoms in the outer flesh tissue, close to the peel. Storage at $5{ }^{\circ} \mathrm{C}$ without a perforated plastic bag was the best condition to maintain the postharvest quality of the pitaya fruit.

Keywords: chilling injury, decay, dragon fruit, pitahaya, weight loss

\section{Introduction}

Pitaya (Hylocereus undatus) is an exotic fruit also known as pitahaya, dragon fruit, strawberry pear, and thang. It is a member of the Cactaceae family, and native to the tropical forest regions of Mexico and Central and South America (Mizrahi et al., 1997). Pitaya is a recently cultivated fruit with important nutritional properties that has been commercialized and consumed in many parts of the world (Mizrahi and Nerd, 1999; Wybraniec and Mizrahi, 2002; Bellec et al., 2006). H. undatus is a medium to large berry with red peel and green or red fleshy scales. The flesh is sweet and white with numerous tiny black seeds, and is consumed fresh or used for juice, jellies, marmalades, jams, wine, and beverages (Wybraniec and Mizrahi, 2002; Chuah et al., 2008).

Pitaya is a non-climacteric fruit that reaches the best eating quality when harvested ripe, decreasing thereafter during storage (Nerd and Mizrahi, 1999; Nerd et al., 1999; Chien et al., 2007). Being a newly cultivated crop, there have been limited studies focused on extending the postharvest quality of the pitaya fruit (Nerd et al., 1999; To et al., 2002; Chien et al., 2007; Wall and Khan, 2008; Chutichudet and Chutichudet, 2011). Therefore, additional research-based information is needed to develop postharvest techniques that maintain fruit quality and increase fruit availability in the marketplace.

The main postharvest problems of the pitaya fruit are mechanical injury, chilling injury, decay, and water loss (Nerd et al., 1999; Wall and Khan, 2008; Chandran, 2010). Mechanical injury leads to the development of sunken areas from increased water loss. This injury can be avoided by harvesting fruit at the appropriate ripe- ness stages and by careful handling after harvest (To et al., 2002). Chilling injury is characterized by translucency and browning of the outer portion of the flesh, darkening of the scales, as well as fruit softening, shriveling, and poor flavor after exposure to low storage temperatures (Nerd et al., 1999). The temperature below which chilling injury is induced ranges between $5{ }^{\circ} \mathrm{C}$ and $10{ }^{\circ} \mathrm{C}$, depending on the genetic background (genus and species), environmental conditions during the growing season, and ripening stage at harvest (Nerd et al., 1999). Accordingly, the best storage temperature for pitaya fruit (Cereus undatus) grown in Vietnam is $5{ }^{\circ} \mathrm{C}$ (To et al., 2002), whereas other authors have concluded that pitaya fruit (Hylocereus undatus and Hylocereus polyrhizus) grown in Israel should be stored at $10{ }^{\circ} \mathrm{C}$ to decrease quality loss and avoid chilling injury (Nerd et al., 1999). However, H. undatus could also be stored at 5 ${ }^{\circ} \mathrm{C}$, depending on the maturity stage at harvest (Hoa et al., 2006). Since the ideal storage temperature is the lowest temperature that does not trigger chilling injury (To et al., 2002), determining such temperature for each genetic background and growing environment is required to effectively maintain the quality of pitaya fruit after harvest.

Rapid shriveling of the pitaya fruit after harvest is also an important problem that reduces visual quality, storage life, and marketability (Jiang et al., 2002). Previous studies have shown that after cutting from the plant, the shelf-life is rapidly shortened by weight loss and desiccation as a result of transpiration (Ariffin et al., 2009). Accordingly, reducing water loss and shriveling has been shown to maintain quality and extend marketability of fruits after harvest (Paull, 1999; Chutichudet and Chuti- 
chudet, 2011). Packing the dragon fruit in a perforated plastic bag is a potential approach to reduce water loss and rapid shriveling, as has been shown for yellow pitaya (Selinicereus megalanthus Shuman) and other fruit crops highly susceptible to water loss during storage (Crisosto et al., 2001; Garcia and Robayo, 2008). However, fruit exposed to high relative humidity environments are potentially more susceptible to decay (Shin et al., 2007).

Our objectives were to determine the best combination of storage temperature and use of perforated plastic bags to decrease water loss and maintain the postharvest quality of pitaya fruits produced in California.

\section{Materials and Methods}

Pitaya fruits (Hylocereus undatus) were harvested 45 days after flowering from a commercial orchard in

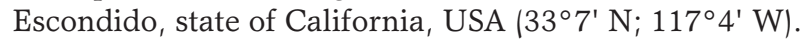
After harvest, fruits were washed in water and allowed to air-dry at $20{ }^{\circ} \mathrm{C}$ and $60 \%$ relative humidity for $24 \mathrm{~h}$. Fruit were individually wrapped with white shredded tissue paper, packed in six fruit corrugated cardboard boxes and shipped overnight to a laboratory. Fruits were randomized into treatment groups and stored at 5,7 , or $10{ }^{\circ} \mathrm{C}$ with and without a perforated polyethylene bag. The bags were low-density polyethylene liners with 61 $\mathrm{cm}$ width, $58 \mathrm{~cm}$ length and $20 \mu \mathrm{m}$ thickness perforated with $1 \mathrm{~cm}$ (diameter) holes, with 30 holes $\mathrm{m}^{-2}$.

Fruits were stored for 20 days at each temperature and then transferred to shelf-life conditions at $20{ }^{\circ} \mathrm{C}$ for five days. During shelf-life, all fruit were held without a perforated bag. The relative humidity at each storage temperature and during shelf-life was $80 \%$. Each treatment was comprised of four replications with four fruits per replication. Fruits were analyzed for decay incidence, decay severity (number of decay spots per fruit), weight loss, respiration rate, firmness, total soluble solids content, and titratable acidity (malic acid equivalents), as described below.

Fruit weight loss was calculated as the difference between fruit weight at harvest and fruit weight after 20 days of storage, as well as the difference between fruit weight at harvest and fruit weight after five days of shelf life. The results were expressed as percentage of fruit weight loss after 20 days of storage and after five days of shelf life by multiplying the respective weight loss by 100 and dividing by the fruit weight at harvest.

Healthy fruit from each replication without visible decay symptoms were sealed in $5 \mathrm{~L}$ jars for $2 \mathrm{~h}$ to monitor respiration. Headspace samples $(10 \mathrm{ml})$ were collected with a syringe and injected into an infrared $\mathrm{CO}_{2}$ analyzer (Horiba, Irvine, CA) to determine the respiration rate based on the amount of $\mathrm{CO}_{2}$ produced per fruit fresh weight over time.

Fruit firmness was measured with a penetrometer (Güss Fruit Texture Analyzer, South Africa) fitted with an $11 \mathrm{~mm}$ probe. Peel was removed on the two opposite sides of each pitaya fruit and firmness recorded on each side. Juice samples were extracted from four fruits per replication by squeezing two cortical wedges cut from both sides of each fruit in two layers of cheese cloth and total soluble solids (TSS) and titratable acidity (TA) were determined on the composite juice. Total soluble solids were quantified with a digital refractometer (Abbe model 10450; American Optical, Buffalo, NY) and titratable acidity was determined with an automatic titrator (Radiometer, Copenhagen, Denmark). For TA, four ml of juice were diluted with $20 \mathrm{ml}$ of distilled water and titrated with $0.1 \mathrm{M} \mathrm{NaOH}$ to $\mathrm{pH}$ 8.2. Malic acid equivalents were calculated based on titratable acidity.

The analysis of variance (ANOVA) for a completely randomized design was performed for each variable. The analyses were accomplished using the SAS statistical package (SAS Institute, 2002). The mean values of four replicate samples were compared using Tukey's test ( $p=0.05)$.

\section{Results and Discussion}

Pitaya fruit produced in California and stored at 5 ${ }^{\circ} \mathrm{C}$ and $7{ }^{\circ} \mathrm{C}$ had better visual appearance after storage for 20 days than fruit stored at $10{ }^{\circ} \mathrm{C}$ (Figure 1). Storage at $5^{\circ} \mathrm{C}$ and $7{ }^{\circ} \mathrm{C}$ maintained a greener color of the bracts, and reduced decay incidence and severity compared with fruit stored at $10{ }^{\circ} \mathrm{C}$ (Figure 1 and 2). The best visual appearance after 20 days of storage and after five days of shelf-life at $20{ }^{\circ} \mathrm{C}$ was observed for fruit stored at $5{ }^{\circ} \mathrm{C}$ without a perforated plastic bag (Figure 1). However, storage of pitaya fruit at $5{ }^{\circ} \mathrm{C}$ resulted in a low level of chilling injury characterized by a thin layer of outer flesh tissue under the peel showing water-soaked symptoms, which was not influenced by the use of a perforated plastic bag (Figure 3).

Studies accomplished in Vietnam and Israel show that the optimal maturity to harvest $H$. undatus fruit is reached between 28 to 30 days after flowering (Nerd et al., 1999; To et al., 2002). In California, however, the minimum quality (color, total soluble solids, titratable acidity, and firmness) required to harvest pitaya fruit is reached between 40 and 45 days after flowering (Merten, 2003). These differences in harvest time have been attributed to different environmental conditions between Southern California and the desert of Israel or the tropics of Vietnam (Merten, 2003).

Although our results show minor chilling injury symptoms in fruit stored at $5{ }^{\circ} \mathrm{C}$ for 20 days, the level of chilling injury observed in our study was much lower than previously reported for the same species grown in Israel and stored for two weeks at $6{ }^{\circ} \mathrm{C}$ (Nerd et al., 1999). These results support the idea that environmental conditions during production affect fruit quality, which determines optimum harvest time, fruit susceptibility to chilling injury, and storage potential of pitaya fruit at low temperatures (Nerd et al., 1999; To et al., 2002). In addition, conditioning yellow pitaya (Acanthocereus pitajaya sensu Croizat) at $25{ }^{\circ} \mathrm{C}$ for $24 \mathrm{~h}$ before storage at $2{ }^{\circ} \mathrm{C}$ 

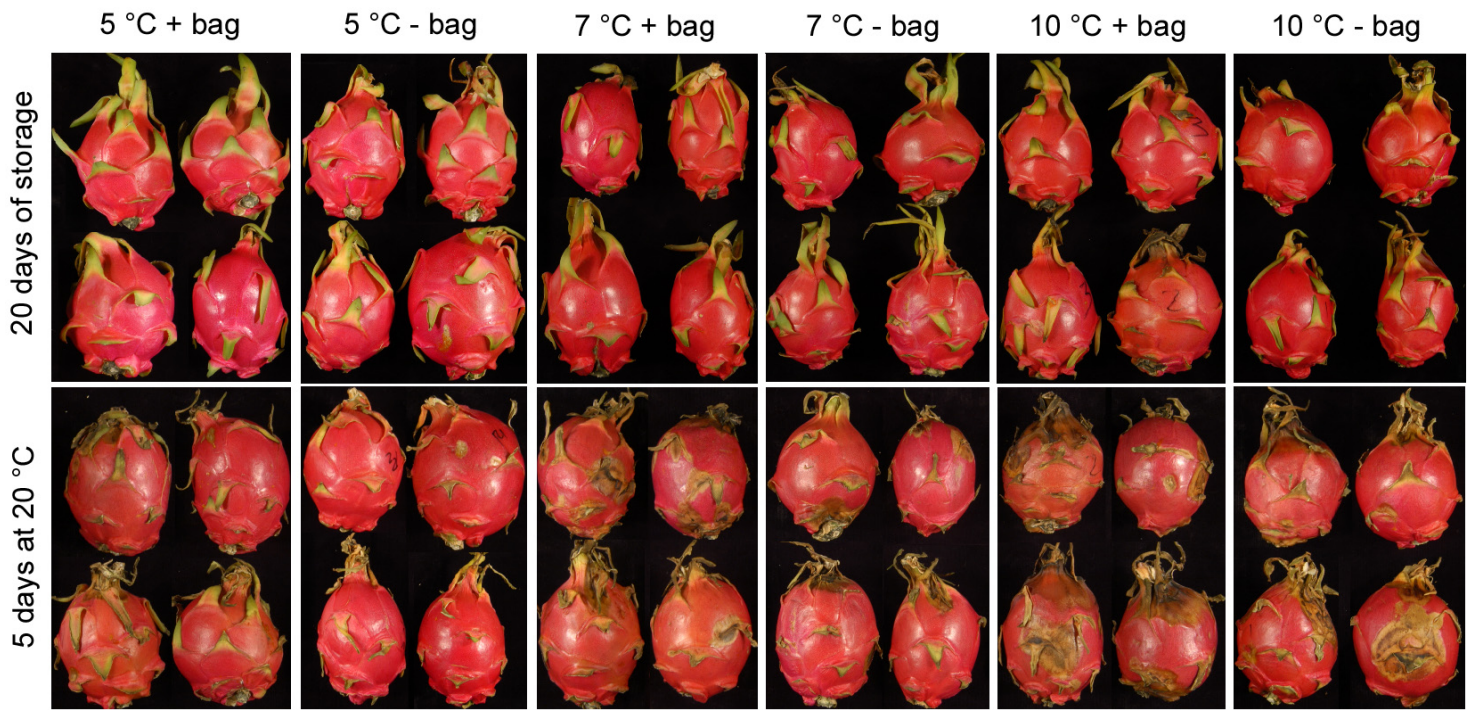

Figure 1 - Pitaya fruit stored at 5,7 , or $10^{\circ} \mathrm{C}$ with and without perforated plastic bags for 20 days (top row) and later transferred to shelf-life at $20{ }^{\circ} \mathrm{C}$ without bags for five days (bottom row).

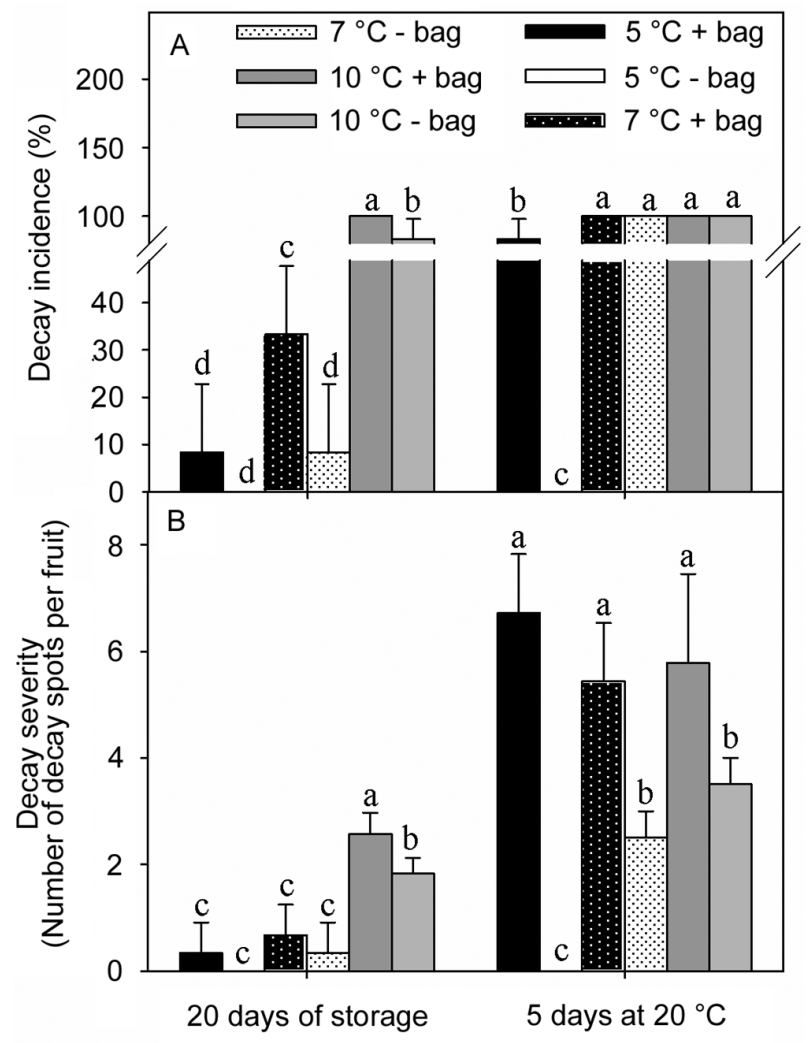

Figure 2 - Decay incidence (A) and decay severity (B) in pitaya fruit after 20 days of storage at 5,7 , or $10{ }^{\circ} \mathrm{C}$ with and without perforated plastic bags and after five days of shelf-life at $20{ }^{\circ} \mathrm{C}$ without bags. Mean values (means \pm standard deviation) with different letters at each evaluation time are different (Tukey's test, $p=0.05$ ).

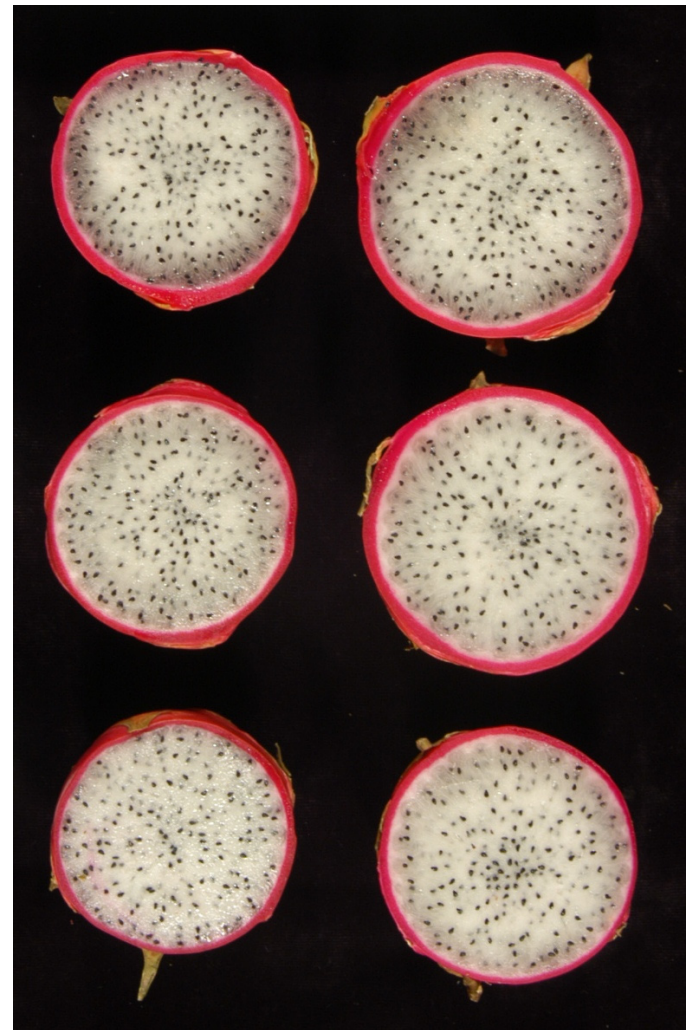

Figure 3 - Middle section of pitaya fruit showing flesh tissue after storage for 20 days at $5{ }^{\circ} \mathrm{C}$ (top row), $7^{\circ} \mathrm{C}$ (middle row), or 10 ${ }^{\circ} \mathrm{C}$ (bottom row) with and without perforated plastic bags plus five days of shelf-live at $20^{\circ} \mathrm{C}$ without bags. Column of fruit on the left were stored with perforated plastic bags. Column of fruit on the right were stored without perforated plastic bags. 
reduced fruit susceptibility to chilling injury, allowing storage of pitaya fruit at such low temperatures (Duenas et al., 2009).

Fruit weight loss during storage without perforated plastic bags was higher at $10^{\circ} \mathrm{C}$ than at 7 or $5{ }^{\circ} \mathrm{C}$ (Figure 4). At all storage temperatures, fruit stored with perforated plastic bags had lower weight loss after 20 days of storage. After shelf-life conditions, the highest weight loss was observed in fruit previously stored at 10 ${ }^{\circ} \mathrm{C}$, with the highest values observed in fruit stored at 10 ${ }^{\circ} \mathrm{C}$ without a perforated plastic bag. The weight loss was greater during five days of shelf-life at $20^{\circ} \mathrm{C}$ than during 20 days of storage at 5,7 , or $10{ }^{\circ} \mathrm{C}$. These results are in agreement with other studies showing that perforated plastic bags can be used to reduce shriveling of crops sensitive to water loss after harvest by maintaining high relative humidity around the commodity (Crisosto et al., 2001; Ben-Yehoshua and Rodov, 2003).

Although perforated plastic bags effectively reduced pitaya fruit weight loss during storage, it also increased the percentage and severity of decay incidence in the fruit. Pitaya fruit stored at $5{ }^{\circ} \mathrm{C}$ without a perforated plastic bag had no decay incidence after storage and shelflife conditions while there was $10 \%$ decay in fruit stored at $5{ }^{\circ} \mathrm{C}$ in a bag (Figure 2). The use of perforated plastic bags also increased the percentage of fruit showing decay incidence during storage at $7{ }^{\circ} \mathrm{C}$ and $10^{\circ} \mathrm{C}$, as well as decay severity at $10{ }^{\circ} \mathrm{C}$ (Figure $2 \mathrm{~A}$ and $2 \mathrm{~B}$ ). Transferring pitaya fruit to $20{ }^{\circ} \mathrm{C}$ after storage resulted in about $80 \%$ decay incidence in fruit stored at $5{ }^{\circ} \mathrm{C}$ with a perforated plastic bag, while fruit stored at $5{ }^{\circ} \mathrm{C}$ without a perforated bag had no decay. Fruit stored at $7{ }^{\circ} \mathrm{C}$ and $10{ }^{\circ} \mathrm{C}$ with and without a perforated plastic bag had $100 \%$ decay incidence after five days at $20{ }^{\circ} \mathrm{C}$ (Figure 2A). Storing pitaya fruit in perforated plastic bags resulted in increased decay

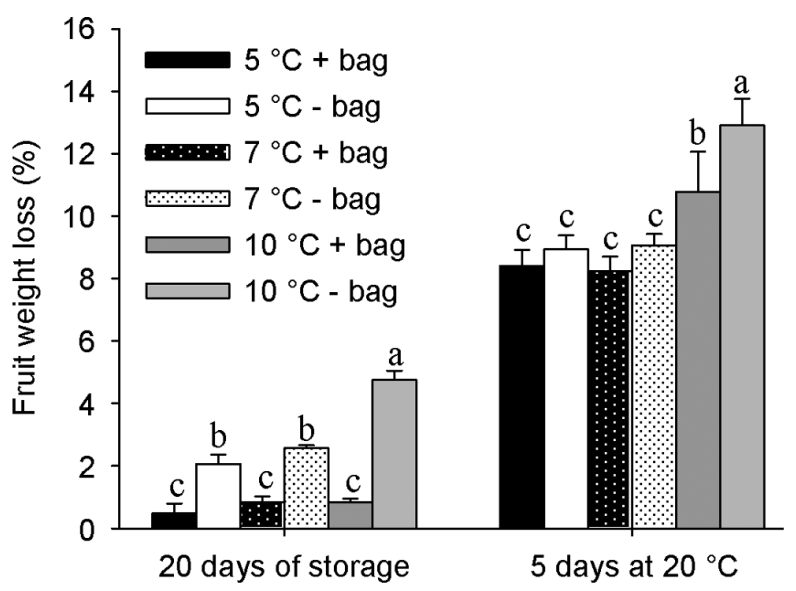

Figure 4 - Weight loss of pitaya fruit after 20 days storage at 5 , 7, or $10{ }^{\circ} \mathrm{C}$ with and without perforated plastic bags and after five days of shelf-life at $20{ }^{\circ} \mathrm{C}$ without bags. Mean values (means \pm standard deviation) with different letters at each evaluation time are different (Tukey's test, $p=0.05$ ). severity during shelf-life at $20{ }^{\circ} \mathrm{C}$ even though the bag had been removed upon transfer (Figure 2B).

The higher levels of decay observed in fruit stored in perforated plastic bags is likely due to an elevated relative humidity that favored growth and development of pathogens in the fruit, especially with high storage temperatures, as has been previously shown in other studies (Lurie et al., 2010). The rapid shriveling of pitaya fruit after harvest reduces visual quality, storage life, and marketability (Jiang et al., 2002); therefore, the use of perforated plastic bags could be beneficial if used in conjunction with decay control measures. Similarly, the use of perforated plastic bags during the shelf-life period would be beneficial to maintain fruit quality, considering the high rates of weight loss; however, decay control would be critical. Hoa et al. (2006) also reported high decay incidence during postharvest handling of pitaya, suggesting that control measures are required

Respiration rates were decreased by reducing fruit storage temperatures (Figure 5). The lowest respiration rates observed after fruit temperatures equilibrated with the storage temperatures, after two days of storage, were at $7{ }^{\circ} \mathrm{C}$, not at $5^{\circ} \mathrm{C}$. The higher respiration rate observed in fruit stored at $5{ }^{\circ} \mathrm{C}$ compared to $7{ }^{\circ} \mathrm{C}$ was probably the result of chilling injury development during storage at $5{ }^{\circ} \mathrm{C}$. McCollum et al. (1995) have also reported elevated respiration rates during chilling injury development in other crop species. There was no effect of perforated bags on the respiration rate of pitaya fruit during storage or shelf-life conditions.

Fruit firmness decreased in all treatments during storage plus shelf-life (Table 1). The highest flesh firmness was observed in fruit stored at $5{ }^{\circ} \mathrm{C}$, which was statistically similar to the flesh firmness of fruit stored at

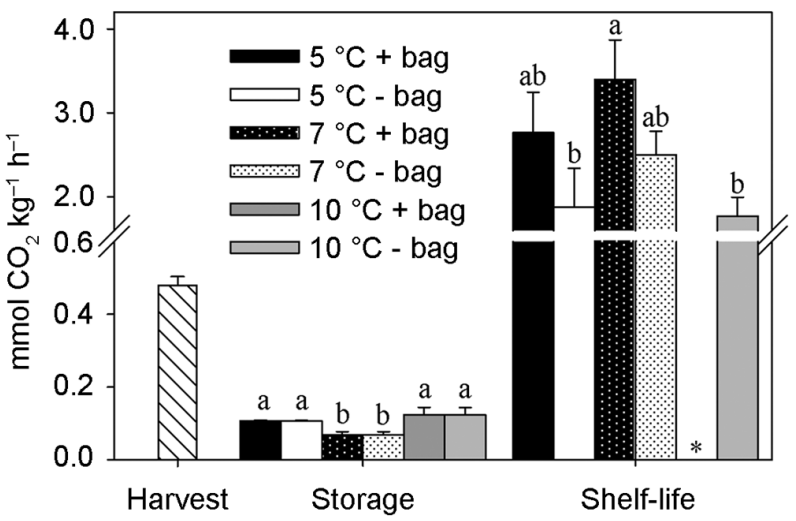

Figure 5 - Respiration rates of pitaya fruit after harvest at $20{ }^{\circ} \mathrm{C}$ (before storage), after two days of storage at 5,7 , or $10^{\circ} \mathrm{C}$ with and without perforated plastic bags, and after two days of shelf-life at $20{ }^{\circ} \mathrm{C}$ without perforated plastic bags. *; Respiration rate was not measured because all fruit were showing decay symptoms. Mean values (means \pm standard deviation) with different letters at each evaluation time are different (Tukey's test, $p=0.05$ ). 
$7^{\circ} \mathrm{C}$. There was no change in total soluble solids content during storage plus shelf-life (Table 1). Titratable acidity decreased in all treatments after storage plus shelf-life (Table 1). The highest acidity values after storage and shelf-life were in fruit stored at $5{ }^{\circ} \mathrm{C}$ and the lowest in fruit stored at $10{ }^{\circ} \mathrm{C}$. The use of perforated plastic bags had no effect on fruit firmness, total soluble solids, or titratable acidity (Table 1). The decrease in fruit firmness and titratable acidity was delayed by storage at $5{ }^{\circ} \mathrm{C}$, compared with higher storage temperatures.

Storage at low temperatures reduces fruit metabolism and delay senescence. Low storage temperatures have been previously reported to delay softening and loss of acidity during storage of $H$. undatus and $H$. polyrhizus fruit (To et al., 2002; Punitha et al., 2010). These authors reported that $H$. undatus harvested 40 days after flowering and stored for 14 days at $5{ }^{\circ} \mathrm{C}$ had no change in firmness or titratable acidity during cold storage, whereas fruit stored at $20^{\circ} \mathrm{C}$ for 14 days had a $32 \%$ reduction in firmness and $11 \%$ decrease in titratable acidity (To et al., 2002). However, Nerd et al. (1999) have shown that both $H$. undatus and $H$. polyrhizus fruit grown in Israel and stored for three weeks at $6{ }^{\circ} \mathrm{C}$ had an $87.5 \%$ decrease in flesh firmness, possibly as a result of a high incidence and severity of chilling injury. Our results show that $H$. undatus fruit grown in California can be stored for 20 days at $5{ }^{\circ} \mathrm{C}$, despite the observation that this storage regime triggers some symptoms of chilling injury. Overall quality maintenance was better at $5{ }^{\circ} \mathrm{C}$ than at 7 or $10{ }^{\circ} \mathrm{C}$.

\section{Conclusions}

The best storage temperature for pitaya fruit cultivated in California was $5{ }^{\circ} \mathrm{C}$, maintaining greener bracts, higher firmness and higher titratable acidity. Storage at $5{ }^{\circ} \mathrm{C}$ also reduced decay incidence and severity, and weight loss. The use of perforated plastic bags may be a potential approach to reduce weight loss if combined with effective decay control strategies during storage and shelf-life of the pitaya fruit.

Table 1 - Flesh firmness, total soluble solids (TSS), and titratable acidity of pitaya fruit at harvest and after 20 days of storage at 5 , 7 , or $10^{\circ} \mathrm{C}$ with and without perforated plastic bags plus five days of shelf-life at $20^{\circ} \mathrm{C}$ without bags.

\begin{tabular}{lcccc}
\hline Temperature $\left({ }^{\circ} \mathrm{C}\right)$ & Bag & Firmness (N) & TSS (\%) & Acidity (\%) \\
\hline At harvest & & $11.6 \mathrm{a}^{*}$ & $10.0 \mathrm{a}$ & $0.361 \mathrm{a}$ \\
5 & + & $9.1 \mathrm{~b}$ & $10.1 \mathrm{a}$ & $0.129 \mathrm{~b}$ \\
& - & $9.3 \mathrm{~b}$ & $10.2 \mathrm{a}$ & $0.163 \mathrm{~b}$ \\
7 & + & $8.5 \mathrm{bc}$ & $10.3 \mathrm{a}$ & $0.112 \mathrm{c}$ \\
& - & $8.7 \mathrm{bc}$ & $10.1 \mathrm{a}$ & $0.090 \mathrm{c}$ \\
10 & + & $8.1 \mathrm{c}$ & $10.7 \mathrm{a}$ & $0.076 \mathrm{~d}$ \\
& - & $8.2 \mathrm{c}$ & $10.0 \mathrm{a}$ & $0.074 \mathrm{~d}$ \\
\hline $\mathrm{CV}(\%)$ & & 8 & 6 & 20 \\
\hline
\end{tabular}

*Mean values with the same letter for each quality evaluation are not different (Tukey's test, $p=0.05$ ).

\section{References}

Bellec, F.L.; Vaillant, F.; Imbert, E. 2006. Pitahaya (Hylocereus spp.): a new fruit crop, a market with a future. Fruits 61: 237250

Ben-Yehoshua, S.; Rodov, V. 2003. Transpiration and water stress. p. 111-159. In: Bartz, J.A.; Brecht, J.K., eds. Postharvest physiology and pathology of vegetables. Marcel Dekker, New York, NY, USA.

Chandran, S. 2010. Effect of film packing in extending shelf life of dragon fruit, Hylocereus undatus and Hylocereus polyrhizus. Acta Horticulturae 875: 389-394.

Chien, P.J.; Sheu, F.; Lin, H.R. 2007. Quality assessment of low molecular weight chitosan coating on sliced red pitayas. Journal of Food Engineering 79: 736-740.

Chuah, T.G.; Ling, H.L.; Chin, N.L.; Choong, T.S.Y.; Fakhru'lRazi, A. 2008. Effects of temperatures on rheological behavior of dragon fruit (Hylocereus sp.) juice. International Journal of Food Engineering 4: 1-28.

Chutichudet, B.; Chutichudet, P. 2011. Effects of chitosan coating to some postharvest characteristics of Hylocercus undatus (Haw) Britton and Rose fruit. International Journal of Agricultural Research 6: 82-92.

Crisosto, C.H.; Smilanick, J.L.; Dokoozlian, N.K. 2001. Table grapes suffer water loss, stem browning during cooling delays. California Agriculture 55: 39-42.

Duenas, Y.M.G.; Narvaez, C.E.C.; Restrepo, L.P.S. 2009. Heat shock improves refrigeration storage performance of yellow pitaya. Agronomia Colombiana 27: 105-110.

Garcia, M.C.; Robayo, P. 2008. Evaluation of the use of passive modified atmospheres and low temperatures on the conservation of yellow pitahaya. Corpoica - Ciencia y Tecnología Agropecuaria 9: 30-39.

Hoa, T.T.; Clark, C.J.; Waddell, B.C.; Woolf, A.B. 2006. Postharvest quality of dragon fruit (Hylocereus undatus) following disinfesting hot air treatments. Postharvest Biology and Technology 41: 6269.

Lurie, S.; Zutahy, Y.; Kaplonov, T.; Lichter, A.; Saks, Y. 2010. The effect of ethanol dip and modified atmosphere on prevention of Botrytis rot of table grapes. Acta Horticulturae 857: 227-234.

McCollum, T.G.; Doostdar, H.; Mayer, R.T.; McDonald, R.E. 1995. Immersion of cucumber fruit in heated water alters chilling-induced physiological changes. Postharvest Biology and Technology 6: 55-64.

Merten, S. 2003. A review of Hylocereus production in the United States. Journal of the Professional Association for Cactus Development 5: 98-105.

Mizrahi, Y.; Nerd, A. 1999. Climbing and columnar cacti: New arid land fruit crops. p. 358-366. In: Janick, J., eds. Perspectives on new crops and new uses. ASHS Press, Alexandria, Egypt.

Mizrahi, Y.; Nerd, A.; Nobel, P.S. 1997. Cacti as crops. Horticultural Reviews 18: 291-319.

Nerd, A.; Mizrahi, Y. 1999. The effect of ripening stage on fruit quality after storage of yellow pitaya. Postharvest Biology and Technology 15: 99-105.

Nerd, A.; Gutman, F.; Mizrahi, Y. 1999. Ripening and postharvest behaviour of fruits of two Hylocereus species (Cactaceae). Postharvest Biology and Technology 17: 39-45. 
Paull, R.E. 1999. Effect of temperature and relative humidity on fresh commodity quality. Postharvest Biology and Technology 15: 263-277.

Punitha, V.; Boyce, A.N.; Chandran, S. 2010. Effect of storage temperatures on the physiological and biochemical properties of Hylocereus polyrhizus. Acta Horticulturae 875: 137-144.

SAS Institute. 2002. Statistical Analysis System. Cary, NC, USA. 200p.

Shin, Y.; Liu, R.H.; Nock, J.F.; Holliday, D.; Watkins, C.B. 2007. Temperature and relative humidity effects on quality, total ascorbic acid, phenolics and flavonoid concentrations, and antioxidant activity of strawberry. Postharvest Biology and Technology 45: 349-357.
To, L.V.; Ngu, N.; Duc, N.D.; Huong, H.T.T. 2002. Dragon fruit quality and storage life: Effect of harvesting time, use of plant growth regulators and modified atmosphere packaging. Acta Horticulturae 575: 611-621.

Wall, M.M.; Khan, S.A. 2008. Postharvest quality of dragon fruit (Hylocereus spp.) after X-ray irradiation quarantine treatment. HortScience 43: 2115-2119.

Wybraniec, S.; Mizrahi, Y. 2002. Fruit flesh betacyanin pigments in Hylocereus cacti. Journal of Agricultural and Food Chemistry 50: 6086-6089. 